\title{
Intrauterine Fetal Deaths: A Study in Tertiary Care Center
}

\author{
Dr. Chaitra $S^{1}$, Dr. Preeti Malapure ${ }^{2}$, Dr. Sandeep ${ }^{3}$, Dr. Ashok Kumar ${ }^{4}$, Dr. Renuka Ramaiah ${ }^{5}$ \\ ${ }^{I}$ Senior resident, Department of Obstetrics and Gynecology, ESIC Medical College and Hospital, India. \\ ${ }^{2,3}$ Junior resident, Department of Obstetrics and Gynecology, ESIC Medical College and Hospital, India. \\ ${ }^{4}$ Assistant t professor, Department of Obstetrics and Gynecology, ESIC Medical College and Hospital, India. \\ ${ }^{5}$ Professor and head of department, Department of Obstetrics and Gynecology, ESIC Medical College and \\ Hospital, India.
}

\begin{abstract}
:
Background: Intrauterine fetal death (IUFD) is very disheartening in both the parent's and the treating obstetrician's life. Many a times the cause of the IUFD is not diagnosed, but when the cause is diagnosed an effective plan can be plotted and appropriate measures can be taken to prevent the same.
\end{abstract}

Objective: To study the prevalence of the IUFD in a tertiary care center, the cause, socio-epidemiological causing the intrauterine fetal death [IUFD].

Materials and Methods: A retrospective observational study was conducted in the ESI Medical College, Bangalore over a period of 3 years between January 2015 and December 2017. A total of 107cases of IUFD was included in the study.

Result: A total of 10,190 deliveries were conducted over a period of 3 years, 107 number of IUFD were recorded, making the prevalence to be $1.05 \%$. In the present study the majority of the cases were multigravidae with a positive past history of abortion (15.8\%), preterm labour (12.2\%) and IUFD (4.6\%). $15(14 \%)$ of the women had no definitive cause of the IUFD. 21(19.6\%) of the women had hypertensive disorders of pregnancy and 1(0.9\%) of them had abruption. 10 (9.3\%) of the women had GDM, with uncontrolled sugar and needed regular alteration in the insulin dose. Vaginal delivery was conducted in $102(95.3 \%)$ of the patients and 5(4.7\%) needed surgical intervention. The commonest complications associated with IUFD was DIC 3 (2.8\%, followed by sepsis 2(1.8\%).

Conclusion: In the present study, the most common cause for IUFD was hypertension complicating pregnancy (19.6\%). In spite of the advance in diagnostic modalities the rate of IUFD is still on the higher side, which is unacceptable. The socio-economic factors had a major role to play with lack of ANC checkup, poverty and illiteracy topping the list. Most of the fetal wastage can be prevented with regular ANC, early detection of medical disorder complicating pregnancy and disorders of pregnancy.

Keywords: Intrauterine fetal death, preeclampsia, abruption, maternal factors

\section{INTRODUCTION}

IUFD is a tragedy not only to the mother but also the family and the treating obstetrician. WHO defined IUFD as "Death prior to expulsion or extraction of a product of human conception from its mother, irrespective of duration of pregnancy and which is not an induced termination of pregnancy, death indicated by fact that after such separation fetus does not show any evidence of life such as beating of heart, pulsation of cord, or definite movement of voluntary muscles. Heartbeats are to be distinguished from transient cardiac contraction; respirations are to be distinguished from fleeting respiratory effort or gasps". (1) expressed as per 1000 of total births Stillbirth is defined as in utero fetal death at 20 weeks of gestation or greater. Whereas according to the perinatal mortality surveillance report (CEMACH) stillbirth is defined as a baby delivered with no signs of life known to have died after 24 completed weeks of pregnancy. ${ }^{(2-4)}$

In a developing country, India the rate of IUFD is 9 per 1000 whereas the rate of perinatal deaths is 32 per 1000 live births according to the Indian census of $2006^{(5)}$. The lowest rate of IUFD is recorded in Finland and Singapore, which is as low as 2 per 1000 births and highest in Pakistan 47 per 1000 and 42 in Nigeria ${ }^{(6)}$. 


\section{Materials AND Methods}

A retrospective observational study was conducted in the ESIC medical college, Bangalore over a period of 3 years from January 2013 to December 2016.

Fetal demise in utero beyond 20 weeks' period of gestation and or weight of more than 500 grams were included in the study. Patient records in the form of age, obstetrics index, associated risk factors in the form of preeclampsia, GDM, oligohydramnios, polyhydramnios, $\mathrm{Rh}$ negative pregnancy were tabulated. Records of mode of delivery, baby details like weight, gross anomalies, liquor, macerated/ fresh still born, placental morphology was recorded. Data thus recorded was analyzed in SPSS 18.0 software. The variables were expressed as mean, and the quantitative variables as percentages.

\section{RESULTS}

In our study we had a total of 10190 deliveries over a period of 3 years. Intrauterine fetal demise 10.5 per 1000 live births. Of whom 72 (67.2\%) had regular ANC.

Table1.Maternal characteristics

\begin{tabular}{|c|c|c|}
\hline Details & Number & $\begin{array}{c}\text { Percentages } \\
(\%)\end{array}$ \\
\hline $\begin{array}{l}\text { AGE } \\
<20 \text { years } \\
21-25 \\
26-30 \\
31-35 \\
>35 \text { years }\end{array}$ & $\begin{array}{l}7 \\
32 \\
47 \\
12 \\
9\end{array}$ & $\begin{array}{l}6.5 \\
29.9 \\
43.9 \\
11.3 \\
8.4\end{array}$ \\
\hline $\begin{array}{l}\text { Parity } \\
\text { Primigravida } \\
\text { multigravida }\end{array}$ & $\begin{array}{l}28 \\
79 \\
\end{array}$ & $\begin{array}{l}26.2 \\
73.8\end{array}$ \\
\hline $\begin{array}{l}\text { Past history } \\
\text { h/o abortion } \\
\text { h/o preterm } \\
\text { h/o IUFD }\end{array}$ & $\begin{array}{l}17 \\
13 \\
5\end{array}$ & $\begin{array}{l}15.8 \\
12.2 \\
4.6 \\
\end{array}$ \\
\hline $\begin{array}{ll}\text { Complains } & \\
\text { Absent } & \text { fetal } \\
\text { movements } & \\
\text { Reduced } & \text { fetal } \\
\text { movements } & \\
\text { Pain abdomen } & \\
\text { Leak p/v } & \\
\end{array}$ & $\begin{array}{l}52 \\
37 \\
10 \\
8\end{array}$ & $\begin{array}{l}48.6 \\
34.6 \\
9.4 \\
7.4\end{array}$ \\
\hline $\begin{array}{ll}\text { Period } & \text { of } \\
\text { gestation(weeks) } \\
20-24 \\
25-28 \\
29-32 \\
33-36 \\
>/=37\end{array}$ & $\begin{array}{l}18 \\
34 \\
34 \\
9 \\
12\end{array}$ & $\begin{array}{l}16.9 \\
31.7 \\
31.7 \\
8.4 \\
11.3\end{array}$ \\
\hline
\end{tabular}

Out of which 52 cases (43.3\%) were referral cases. Majority of the cases $(n=73)$ were multigravida (60.8\%) and $39.1 \%$ were primigravida $(\mathrm{n}=47)$. The mean parity was 2.05 (std deviation-1.0359) Majority of patients were aged less than 30 years $(n=96,80 \%)$ with the mean age of 25.72 (std deviation-4.4964) with 28 to 36 weeks' period of gestation $(n=66,55 \%)$.The mean gestational age was 29.71 weeks with standard deviation of 5.3376 . 40 patients $(33.3 \%)$ had IUFD at $<28$ weeks of gestation. $11.7 \%(n=14)$ of the patients had term IUFD. 91 patients had presented with absent fetal movements $(75.8 \%)$ while $10 \% \quad(\mathrm{n}=12)$ came with decreased fetal movements. $4.2 \%$ $(n=5)$ of patients were admitted with pain and $1.7 \%(n=2)$ with leak per vagina (Table 1$)$

Table2.Causes of IUFD

\begin{tabular}{|l|l|l|}
\hline \multicolumn{1}{|c|}{ Cause of IUFD } & Number & $\begin{array}{c}\text { Percentage } \\
(\%)\end{array}$ \\
\hline $\begin{array}{l}\text { Hypertensive disorder of } \\
\text { pregnancy }\end{array}$ & 21 & 19.6 \\
\hline Abruption & 1 & 0.9 \\
\hline Eclampsia & 4 & 3.7 \\
\hline GDM & 10 & 9.3 \\
\hline Oligohydramnios & 2 & 1.8 \\
\hline Polyhydramnios & 0 & 0 \\
\hline Anemia & 9 & 8.3 \\
\hline Thrombocytopenia & 2 & 1.8 \\
\hline Rh negative pregnancy & 6 & 5.6 \\
\hline Hypothyroidism & 8 & 7.3 \\
\hline Anomalies & 22 & 20.4 \\
\hline Cord accidents & 8 & 7.3 \\
\hline Jaundice & 0 & 0 \\
\hline Unexplained & 15 & 14 \\
\hline
\end{tabular}

Table 2 depicts the cause of the IUFD, 21 $(19.6 \%)$ of the women had elevated blood pressure and10(9.3\%) of them had gestation hypertension.

$15(14 \%)$ of the women had no known cause of IUFD. $6(5.6 \%)$ of the women had a rhesus negative blood group and the cause of the IUFD was hydrops in all of them.

Table3.Fetal Characteristic

\begin{tabular}{|l|l|l|}
\hline \multicolumn{1}{|c|}{ Fetal characteristics } & Number & $\begin{array}{c}\text { Percentage } \\
\text { \% }\end{array}$ \\
\hline Anomalies & 22 & 20.5 \\
\hline Meconium stained liquor & 26 & 24.3 \\
\hline Macerated & 35 & 32.7 \\
\hline Still birth & 72 & 67.2 \\
\hline $\begin{array}{l}\text { Tight loop of cord round } \\
\text { the neck }\end{array}$ & 14 & 13 \\
\hline True knots & 6 & 5.6 \\
\hline
\end{tabular}

Anomalies was noted in 22 women, of whom 16 had not performed the anomaly scan and 6 of them had a significant previous history of anomalies fetus. $72(67.2 \%)$ of the feus where 
still born in comparison to macerated fetus which was noted in 35 (32.7\%) of the fetus.

Table4. Maternal Complications

\begin{tabular}{|l|l|l|}
\hline \multicolumn{1}{|c|}{ Complication } & Number & Percentage \\
\hline DIC & 4 & 3.7 \\
\hline Sepsis & 9 & 8.4 \\
\hline Acute renal failure & 2 & 1.8 \\
\hline Maternal mortality & 0 & 0 \\
\hline
\end{tabular}

Maternal complication in our study was predominantly sepsis seen in $8.4 \%$ of the women of, more so in women with prolonged leak and prolonged labor. DIC was seen in 4 women, and they were managed in the medical ICU and with blood / blood product transfusions.

\section{DisCUSSION}

In the study we have conducted in our center we found the prevalence to be $1.05 \%$, in comparison to the study conducted by Divya et al where the incidence was 29.2 per 1000 and Maleckiene L et al the IUFD was 40 per $1000^{(7-}$ ${ }^{8)}$. The rate of the IUFD varies widely over the country with a still $14 \%$ in Karnataka ${ }^{(8,9)}$. Patel et al reported that the incidence was much higher in those women who tend to seek admission on emergency grounds $56(70 \%)$ in comparison to registered admission $24(30 \%){ }^{(10)}$. $73.8 \%$ of the women where multigravida whereas as $26.2 \%$ where primigravida in our study, which is the marginally reduced in the study done by Divya et al (60.8\%) and Korde$\mathrm{NV}$ et al $(51.6 \%)^{(7,11)}$.

In our study women between the age group $<30$ years had the highest prevalence of IUFD of $80.3 \%$ and women more than 35 years was $8.6 \%$, which was similar in the study conducted by divya et al. of $80 \%^{(7)}$. $4.6 \%$ of the women had a previous history of IUFD at the similar gestation age and also all of them had a history of elevated blood sugar. $63.5 \%$ of the women had IUFD between 25-32 weeks' period of gestation and $11.3 \%$ of them after 37 weeks' period of the gestation. This is comprisable to the study by Patel et al, 50(62.5\%) was between 25-32 weeks $^{(10)}$ past history of recurrent loss was noted in $11.2 \%$, of whom $6.5 \%$ where proven case of Antiphospholipid Antibody Syndrome (APS) and where treated with low dose of aspirin and low molecular weight heparin ${ }^{(12)} .48 .6 \%$ of the women had absent fetal movement, $34.6 \%$ of the women had reduced fetal movement and $9.4 \%$ had history of pain abdomen, in comparison to the study conducted by divvy et al where $75.8 \%$ of the patients had presented with absent fetal movements while $10 \%$ had come with decreased fetal movements.

Over the past years the causative agent for IUFD have been on a changing trend .In a developed country the incidence of IUFD is reduced and also if the etiological pattern for the same ${ }^{(13)}$. The most common causes in the past was syphilis, $\mathrm{Rh}$ isoimmunisation and postdated which is no longer significant due to the usage of Rh immune prophylaxis, routine ANC check-up and VDRL screening ${ }^{(14)}$. Intrapartum loss is very much reduced due to active use of electronic fetal monitoring. In today's world newer causes like thrombophillias, intrahepatic cholestasis of pregnancy has been recognized. In our study $19.6 \%$ had hypertension complicating pregnancy, $9.3 \%$ had gestation hypertension and $0.9 \%$ of them had abruption. Many of the other study have reported the cause of PIH and eclampsia to be $33.7 \%$. Divya et al had reported the prevalence of the GDM to be 4.2 whereas Anjali $\mathrm{C}$ to be $4.1 \%{ }^{(15)}$. In present study, $14 \%$ had unexplained IUFD as compared to $38.7 \%$ in Patel S et al study and Singh $\mathrm{N}$ et al it was 33\%, which was very much higher ${ }^{(10)}$.

Meconium stained liquor was noted in $24.3 \%$, anomalies in 20.5 , loop round the neck was $13 \%$ and true knot in 5.6\%.in comparison to the study conducted by Divya et al was $4.2 \%$ of women with loop round the neck and $0.8 \%$ with true $\operatorname{knot}^{(7)} \cdot 67.2 \%$ were fresh still births whereas $32.7 \%$ were macerated which is the very similar to study by Katherine J. Gold et al in which 33 $(70 \%)$ foetuses were fresh and $14(30 \%)$ were macerated (16)

A hospital stay of $>7$ days was noted in $10.2 \%$ of the women, predominantly in those who needed ICU care, which was similar to the study conducted by Divya et al (7). $3.7 \%$ of the women has DIC, $8.4 \%$ of them developed sepsis and $1.8 \%$ of them were diagnosed to have acute renal failure. There was no maternal mortality due to IUFD in our centre. $12.14 \%$ of the women needed blood transfusion in our study which was similar to that in the study conducted by Divya et al (7)..

\section{REFERENCES}

[1] F. Cunningham, Kenneth Leveno, Steven Bloom, Catherine Y. Spong, Jodi Dashe. Stillbirth. In: F. Cunningham, Kenneth Leveno, Steven Bloom, Catherine Y. Spong, Jodi Dashe, eds. Williams Obstetrics. 24th ed. New 
York: McGraw-Hill Professional; 2014: 661666.

[2] Confidential Enquiry into Maternal and Child Health (CEMACH). Perinatal Mortality 2007:United Kingdom. CEMACH: London, 2009.

[3] World Health Organization (WHO). Neonatal and perinatal mortality, country, regional and global estimated. Department of Making Pregnancy safer. Geneva: WHO, 2004.

[4] Silver RM, Varner MW, Reddy U. Work-up of stillbirth: a review of the evidence Am J Obstet Gynecol. 2007;196(5):433-44.

[5] Estimates of mortality indicators-Census of India website-vital statistics Chapter $4 \mathrm{Pg} 81$, statement 512010

[6] Lawn JE, Gravett MG, Nunes TM, Rubens CE, Stanton C. The GAPPS Review Group. Global report on preterm birth and stillbirth (1 of 7): definitions, description of the burden and opportunities to improve data. BMC Pregnancy Child-birth. 2010;(Suppl 1):S1,1471-2393.

[7] Balu D, Nayak A, Swarup A. A study of intrauterine fetal death in a tertiary care hospital. Int $\mathbf{J}$ Reprod Contracept Obstet Gynecol 2015;4:2028-31.

[8] Maleckiene L, Nadisauskiene R, Stankeviciene J, Cizauskas A, Bergstrom S. A case reference study on fetal bacteremia and late fetal death of unknown etiology in Lithuania. Acta Obstet Gynecol Scand. 2000;79:1069-74.

[9] Bhati DK. Stillbirths: A high magnitude public health issue in India .South East Asia Journal of Public Health. 2013;3(1):3-9.

[10] Patel S, Thaker R, Shah P, Majumder S. Study of causes and complications of intra uterine fetal death (IUFD). Int J Reprod Contracept Obstet Gynecol. 2014;3:931-5.

[11] Korde NV, Gaikwad P. Causes of stillbirth. J Obstet Gynaecol India. 2008;58(4):314-7.

[12] Rai R, Regan L. Antiphospholipid in pregnancy. Curr Obstet Gynaecol. 1998;8:32.

[13] Jahanfar Sh, Ghiyasi P,Haghani H Sh ,Risk factors related to intra uterine fetal death in Iran ,A case control study.Shiraz E-Medical journal ,Vol.6,3,\&4 July and October 2005.

[14] Ruth C. Frets, Etiology and prevention of still birth, American journal of obstetrics and gynecology (2005) 193, 1923-35.

[15] Choudhary A, Gupta V. Epidemiology of Intrauterine Fetal Deaths: A Study in Tertiary Referral Centre In Uttarakhand. Journal of Dental and Medical Sciences. 2014;13(3):3-6.

[16] Gold KJ, Abdul-Mumin AS. Assessment of "fresh" versus "macerated" as accurate markers of time since intrauterine fetal demise in lowincome countries. Int $\mathbf{J}$ Gynaecol Obstet. 2014;125(3):223-7.

Citation: Dr. Chaitra S, Dr. Preeti Malapure, Dr. Sandeep, Dr. Ashok Kumar \& Dr. Renuka Ramaiah, "Intrauterine Fetal Deaths: A Study in Tertiary Care Center". ARC Journal of Gynecology and Obstetrics.2018; 3(1):7-10. dx.doi.org/10.20431/2456-0561.0301002.

Copyright: (C) 2018 Authors. This is an open-access article distributed under the terms of the Creative Commons Attribution License, which permits unrestricted use, distribution, and reproduction in any medium, provided the original author and source are credited. 